
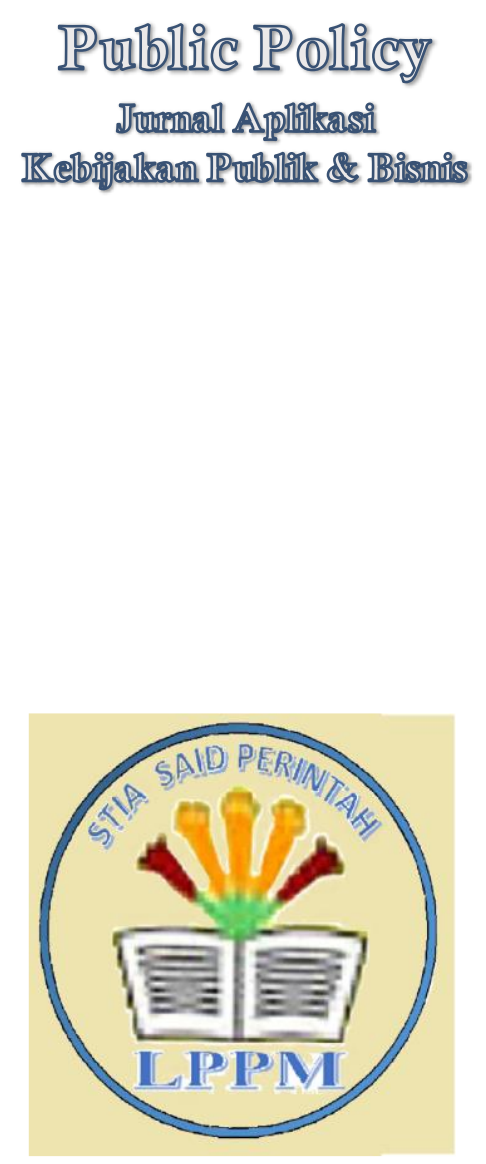

LPPM STIA Said Perintah

Volume 2, No. 1, Maret 2021

https://stia-saidperintah.e-journal.id/ppj

\section{Determinan Kinerja Sistem Informasi Akuntansi dimoderasi oleh Pendidikan dan Pelatihan}

\author{
Victor Pattiasina' \\ Muhamad Yamin Noch ${ }^{2}$ \\ (Penulis Korespondensi) \\ Saling ${ }^{3}$ \\ Melyanus Bonsapia 4 \\ Andarias Patiran ${ }^{5}$ \\ 1,2,3 Universitas Yapis Papua \\ ${ }^{4,5}$ Universitas Ottow Geissler Papua \\ abienoch12@gmail.com
}

\begin{abstract}
This study examines the determinants of accounting information system performance (a study at PT. PLN Company Jayapura district unit). Testing was carried out on a sample of 71 respondents. The sample method used was purposive sampling. Data collection was carried out by direct survey. Hypothesis testing is tested empirically using moderated regression. The results showed that the technical ability of the apparatus had no effect on the performance of the accounting information system at PT. PLN Company Unit Jayapura Regency, user involvement affects the performance of the accounting information system on the performance of the accounting information system at PT. PLN Jayapura Regency Unit, the sophistication of personnel technology has an effect on the performance of the accounting information system. The performance of the accounting information system at PT. PLN Jayapura Regency Unit Company, training moderates the technical ability of the apparatus on the performance of the accounting information system at PT. PLN Company Unit Jayapura Regency, training moderates user involvement in the performance of the accounting information system at PT. PLN Jayapura Regency Unit and the latest education and training moderated the sophistication of personnel technology on the performance of the accounting information system at PT. PLN Jayapura Regency Unit Company.

Keywords : Performance of Accounting Information Systems, Education and Training
\end{abstract}




\section{Pendahuluan}

Perkembangan teknologi informasi berlangsung sangat cepat dan pesat pada peningkatan penggunaan teknologi komputer merupakan dampak dari perkembangan teknologi informasi. Sebelum terjadi peningkatan kemajuan teknologi informasi, sebagian besar waktu yang digunakan oleh individu didalam perusahaan dan penggunaan sistem informasi dilakukan secara manual. Setelah terjadi peningkatan perkembangan teknologi informasi, banyak perusahaan beralih pada pendayagunaan sistem informasi yang berbasis komputer karena akan memudahkan dan mempercepat manajemen untuk mengolah informasi yang akan dinput (Adiwinata \& Sujana, 2019).

Undang-Undang Republik Indonesia No 25 Tahun 2009 Tentang Pelayanan Publik mendefinisikan bahwa pelayanan publik adalah kegiatan atau rangkaian kegiatan dalam rangka pemenuhan kebutuhan pelayanan sesuai dengan peraturan perundangundangan bagi setiap warga negara dan penduduk atas barang, jasa dan pelayanan administratif yang disediakan oleh penyelenggaraan pelayanan publik. Penyelenggara Pelayanan Publik adalah Penyelenggara setiap institusi penyelenggara negara, korporasi, lembaga independen yang dibentuk berdasarkan Undang-Undang untuk kegiatan pelayanan publik, dan badan hukum lain yang dibentuk semata-mata untuk kegiatan pelayanan publik. Dalam Organisasi penyelenggara pelayanan publik yang selanjutnya disebut Organisasi.

Dalam menunjang kinerja PT. PLN (Persero) sudah menggunakan Sistem Informasi Akuntansi (SIA). Perkembangan teknologi informasi telah banyak membantu meningkatkan kinerja SIA. Peningkatan penggunaan teknologi komputer sebagai salah satu bentuk teknologi informasi telah mengubah pemrosesan data akuntansi secara manual menjadi otomatis. Sejak tahun 2007, PT. PLN (Persero) telah menggunakan sistem informasi akuntansi yang terintegrasi satu sama lain, yaitu System Application and Product (SAP). SAP adalah suatu software yang dikembangkan untuk mendukung suatu organisasi dalam menjalankan kegiatan operasionalnya secara lebih efisien dan efektif. SAP juga merupakan software Enterprise Resources Planning (ERP), yaitu suatu tools IT dan manajemen untuk membantu perusahaan merencanakan dan melakukan berbagai aktivitas sehari-hari. SAP terdiri dari sejumlah modul/aplikasi yang mempunyai kemampuan mendukung semua transaksi yang perlu dilakukan suatu perusahaan dan tiap aplikasi bekerja secara berkaitan satu dengan yang lainnya (Seto, 2013). Pada kebutuhan dan persepsi manajerial, lingkungan usaha dan teknologi informasi yang lebih 
relevan dan tepat waktu untuk pengambilan keputusan. Beberapa perusahaan manajemen keuangan merasakan bahwa informasi keuangan yang disediakan oleh sistem informasi perusahaan tidak lagi memadai untuk memenuhi semua kebutuhan perusahaan, hal ini membuktikan bahwa informasi merupakan hal yang pokok dalam suatu perusahaan sehingga dapat dibaratkan sebagai nafas kehidupan perusahaan. Bagian terpenting dari seluruh infomasi yang dibutuhkan manajemen khususnya manajemen perusahaan adalah informasi akuntansi (Ningrum, 2019).

Sistem informasi akuntansi merupakan penyedia informasi keuangan yang dibutuhkan oleh pihak-pihak yang berkepentingan dengan perusahaan. Pihak-pihak yang berkepentingan dalam penggunaan informasi keuangan yakni pihak eksternal dan internal. Tujuan kinerja sistem informasi akuntansi adalah untuk memberikan gambaran apakah suatu kinerja yang ada sudah sesuai dengan yang dibutuhkan serta sesuai dengan tujuan. Adapun faktor-faktor yang mempengaruhi sistem informasi akuntansi, diantaranya; kemampuan teknis personal, keterlibatan pemakai, pelatihan dan pendidikan serta kecangihan teknologi informasi.

Kemampuan teknik personal dalam pengunaan informasi pada suatu perusahaan dapat dilihat dari kemudahan pemakai dalam mengidentifikasi data, mengakses data dan menginterpretasikan data tersebut. Kemampuan teknik personal akuntansi yang baik akan mendorong pemakai untuk menggunakan sistem informasi akuntansi sehingga kinerja sistem informasi akan lebih tinggi. Kemampuan teknik personal merupakan suatu hal yang tidak terlepas dari penerapan teknologi, selain itu keberadaan manusia sangat berperan penting dalam penerapan teknologi (Putri dan Dharmadiaksa, 2015). Menurut (Ardiwinata \& Sujana, 2019) kemampuan pemakai dapat dilihat dari bagaimana pemakai sistem menjalakan sistem informasi yang ada.

Faktor pertama yang mempengaruhi Sistem Informasi Akuntansi adalah kemampuan teknis personal. Berdasarkan penelitian yang dilakukan oleh (Abhimantra dan Suryanawa 2016) menunjukkan bahwa, kemampuan teknik personal tidak berpengaruh pada kinerja sistem informasi akuntansi. Selanjutnya menurut Fani, dkk (2015) menunjukan bahwa, kemampuan teknik pemakai, secara parsial dan simultan berpengaruh positif dan signifikan terhadap kinerja sistem informasi akuntansi. Kemudian menurut (Adiwinata and Sujana 2019) hasil penelitian ini menunjukkan bahwa kemampuan teknik personal, berpengaruh positif dan signifikan terhadap kinerja sistim informasi akuntansi. 
Determinan selanjutnya dari Sistem Informasi Akuntansi yaitu keterlibatan pemakai yang menurut penelitian (Abhimantra dan Suryanawa 2016) menyimpulkan bahwa keterlibatan pemakai berpengaruh positif pada kinerja sistem informasi akuntansi. Hasil tersebut selanjutnya didukung oleh Ardiwinata and Sujana (2019) berhasil membuktikan bahwa keterlibatan pemakai berpengaruh positif dan signifikan terhadap kinerja sistem informasi akuntansi. Sedangkan berdasarkan penelitian Alchan, dkk (2016) menyimpulkan hasil yang berbeda yakni, keterlibatan pemakai tidak berpengaruh terhadap kinerja sistem informasi akuntansi pada PT. PLN (Persero) Distribusi Jawa Barat. Sejalan dengan kedua hasil penelitian diatas Abhimantra dan Suryanawa (2016) dan Satria, dkk (2019) yan juga mengungkapkan hasil yang sama yakni, pelatihan dan pendidikan berpengaruh positif pada kinerja sistem informasi akuntansi. Sedangkan ada hasil yg berbeda menurut (Alchan, dkk (2016) yaitu program pendidikan dan pelatihan pemakai tidak berpengaruh terhadap kinerja sistem informasi akuntansi di PT. PLN (Persero) Distribusi Jawa Barat.

Faktor lain yang dapat mempengaruhi kinerja sistem informasi akuntansi adalah kecanggian teknologi informasi. Menurut Ayu Febriyanti, (2018) kecanggihan teknologi yang ada tidak akan ada artinya jika dalam perencanaan sistemnya tidak memperhatikan faktor manusia sebagai pemakainya, maka dapat dipastikan akan terjadi banyak hambatan yang disebabkan adanya ketidaksesuaian antara teknologi yang digunakan dengan pemakainya. Hasil penelitian dari Ratnasih, dkk (2017) menunjukkan bahwa secara parsial kecanggihan teknologi informasi berpengaruh positif dan signifikan terhadap kinerja sistem informasi akuntansi. Hasil penelitian lainnya dari Fani, dkk (2015) menyimpulkan bahwa kecanggihan teknologi informasi secara parsial dan simultan berpengaruh positif dan signifikan terhadap kinerja sistem informasi akuntansi.

Berdasarkan uraian-uraian diatas menunjukan adanya kesenjangan penelitian (research gap) yang memotivasi penulis untuk melakukan pengujian ulang dengan mengadopsi kerangka konseptual kajian empiris diatas. Tujuan penelitian ini adalah untuk menganalisis determinan sistim informasi akuntasi (kemampuan teknis personal, keterlibatan pemakai dan kecanggihan teknologi informasi) yang dimoderasi oleh pendidikan dan pelatihan pada PT. PLN Persero Unit Layanan Pelanggan Kabupaten Jayapura. 


\section{Kerangka Teoritis Dan Pengembangan Hipotesa Penelitian}

Berdasarkan uraian yang telah diteliti sebelumnya maka dalam penelitian ini akan menguji Determinan yang mempengaruhi kinerja sistim informasi akuntansi dengan pelatihan dan pendidikan sebagai variabel moderasi pada PT. PLN Persero Unit Layanan Pelanggan Kabupaten Jayapura. Gambaran kerangka pemikiran dalam penelitian sebagai berikut:

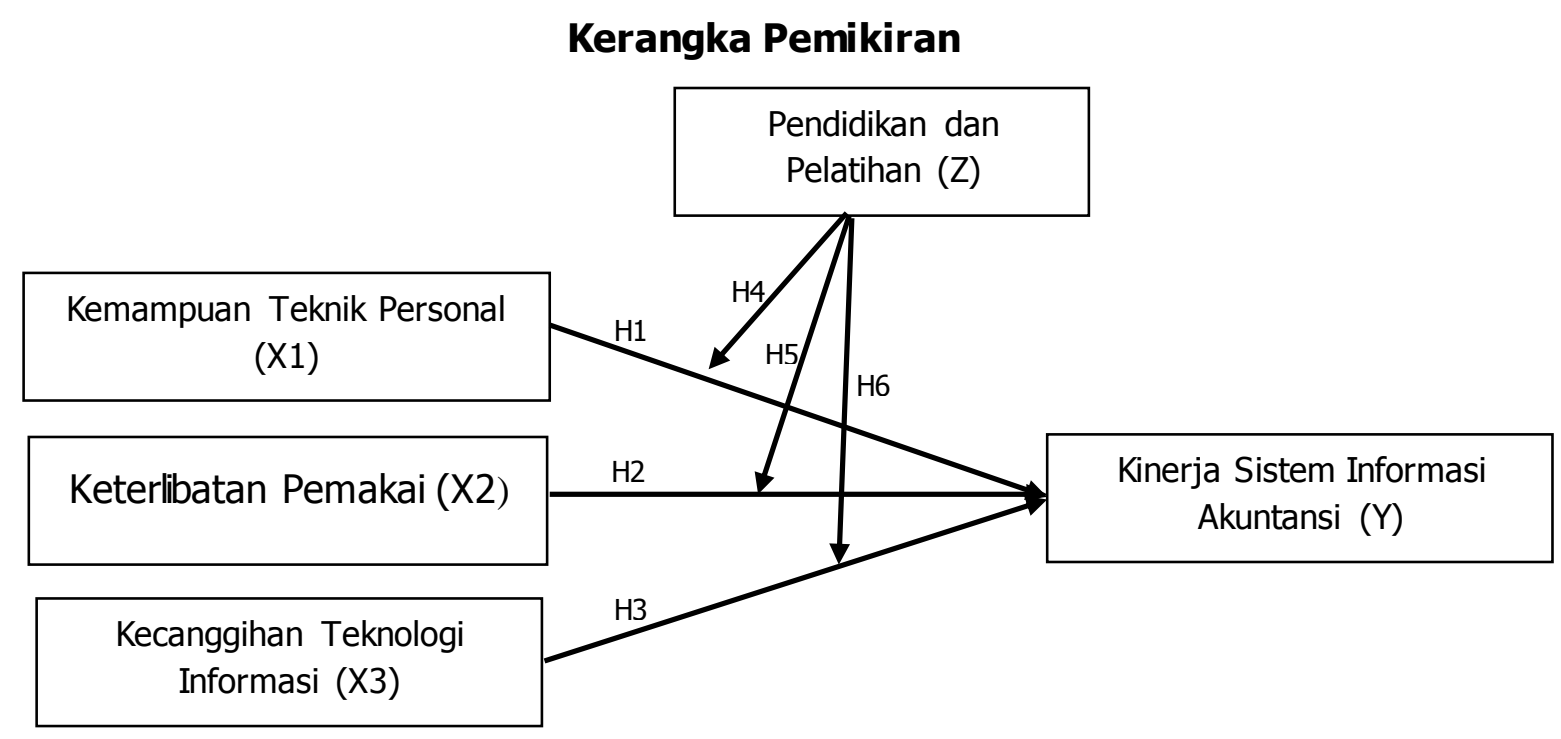

\section{Pengaruh Kemampuan Teknik Personal Terhadap Kinerja Sistem Informasi Akuntansi}

Menurut Putri dan Dharmadiaksa (2015) kemampuan teknik personal adalah suatu hal yang tidak terlepas dari penerapan teknologi, selain itu keberadaan manusia sangat berperan penting dalam penerapan teknologi. Sedangan Abhimantra dan Suryanawa (2016) bahwa kemampuan teknik personal, berpengaruh positif pada kinerja sistem informasi akuntansi. Selanjutnya menurut (Fani, dkk (2015) menunjukan bahwa, kemampuan teknik pemakai, secara parsial dan simultan berpengaruh positif dan signifikan terhadap kinerja sistem informasi akuntansi. Kemudian menurut Ardiwinata and Sujana (2019) Hasil penelitian ini menunjukkan bahwa kemampuan teknik personal, berpengaruh positif dan signifikan terhadap Kinerja sistim informasi akuntansi, maka peneliti merumuskan Hipotesis pertama yakni:

$\mathrm{H}_{1}$ : Kemampuan teknik personal berpengaruh terhadap sistem informasi akuntansi.

\section{Pengaruh Keterlibatan Pemakai Terhadap Kinerja SistemInformasi Akuntansi}

Menurut penelitian Abhimantra dan Suryanawa (2016) menyimpulkan bahwa Hasil penelitian menunjukkan bahwa keterlibatan pemakai berpengaruh positif pada kinerja 
sistem informasi akuntansi. Peneliti lain yakni Ardiwinata dan Sujana (2019) Hasil penelitian ini menunjukkan bahwa keterlibatan pemakai berpengaruh positif dan signifikan terhadap kinerja sistem informasi akuntansi. Sedangkan berdasarkan penelitian dari Alchan, dkk (2016) menyimpulkan hasil yang berbeda yakni, keterlibatan pemakai tidak berpengaruh terhadap kinerja sistem informasi akuntansi pada PT. PLN (Persero) Distribusi Jawa Barat.

$\mathrm{H}_{2}$ : Keterlibatan pemakai berpengaruh terhadap kinerja sistem informasi akuntansi.

\section{Pengaruh Kecanggihan Teknologi Terhadap Kinerja Sistem Informasi Akuntansi}

Menurut Komang Ratnasih and Sujana (2017), menunjukkan bahwa secara parsial kecanggihan teknologi informasi berpengaruh positif dan signifikan terhadap kinerja sistem informasi akuntansi. Peneliti lainnya Fani,dkk (2015) menyimpulkan bahwa kecanggihan teknologi informasi secara parsial dan simultan berpengaruh positif dan signifikan terhadap kinerja sistem informasi akuntansi.

$\mathrm{H}_{3}$ : Kecanggihan teknologi informasi berpengaruh terhadap sistem informasi akuntansi.

\section{Pendidikan dan Pelatihan Moderasi Pengaruh Kemampuan Teknik Personal}

\section{Terhadap Kinerja Sistem Informasi Akuntansi}

Kemampuan teknik personal tidak lepas dari penerapan teknologi, kemampuan pemakai dapat dilihat dari bagaimana pemakai sistem dapat menggunakan Kinerja sistim informasi akuntansi hal ini penting dalam mengoperasikan agar sistim dapat beroperasi secara maksimal. Terdapat perbedaan dengan penelitian (Gusi Putu Lestara Permana, 2020) menyatakan bahwa pendidikan dan pelatihan tidak mampu memperkuat kemampuan teknik personal pada kinerja sistem informasi akuntansi.

$\mathrm{H}_{4}$ : Pendidikan dan pelatihan memoderasi pengaruh kemampuan teknik personal terhadap kinerja sistim informasi akuntansi.

\section{Pendidikan dan Pelatihan Moderasi Pengaruh Keterlibatan Pemakai Terhadap Kinerja Sistem Informasi Akuntansi}

Keterlibatan pemakai yang semakin sering akan meningkatkan kinerja sistem informasi akuntansi dikarenakan adanya hubungan positif antara keterlibatan pemakai terhadap kinerja sistem informasi akuntansi. Adanya keterlibatan pemakai dapat meningkatkan penerimaan sistem oleh pemakai. Melalui adanya pendidikan dan pelatihan dapat meningkatkan pemahaman pemakai tentang sistem informasi yang digunakan, selain itu dapat meningkatkan komitmen dan ketelibatan pemakai dalam 
pengembangan sistem, sehingga pemakai dapat menggunakan sistem informasi dan dapat meningkatkan kualitas kinerja sistem informasi akuntansi dalam pengembangan sistemnya. Pernyataan ini konsisten dengan penelitian I Wayan Andika Suryana, (2020), yang menunjukan bahwa pendidikan dan pelatihan mampu memperkuat keterlibatan pemakai pada Kinerja sistem infomasi akuntansi.

Penggunaan pedidikan dan pelatihan sebagai variabel pemoderasi, dikarenakana adanya perbedaan hasil variabel keterlibatan pemakai. Variabel pendidikan dan pelatihan personal dapat memoderasi pengaruh keterlibatan pemakai terhadap kinerja sistem informasi akuntansi.

$\mathrm{H}_{5}$ : Pendidikan dan Pelatihan memoderasi pengaruh keterlibatan pemakai terhadap kinerja sistim informasi akuntansi.

\section{Pendidikan dan Pelatihan Moderasi Pengaruh Kecanggian Teknologi Personal Terhadap Kinerja Sistem Informasi Akuntansi}

Menurut Haag den Keen (1996) dalam Nugerahamawati (2013), teknologi informasi adalah seperangkat alat yang memebantu anda bekerja dengan informasi dan melakukan tugas - tugas yang berhubungan dengan pemrosesan informasi. Teknologi informasi dapat berjalan dengan efektif apabila anggota dalam organisasi dapat menggunakan teknologi dengan baik dan sangat penting bagi individu. Menurut penelitian yang dilakukan oleh (Alannita, 2014) dan (Fani, Luh Nanda Yogita \& Ayu, 2015) menunjukan bahwa kecanggihan teknologi informasi terdapat pengaruh yang signifikan terhadap Kinerja Individu.

Penggunaan pedidikan dan pelatihan sebagai variabel pemoderasi, dikarenakanaadanya perbedaan hasil variabel kecanggian teknologi personal. Variabel pendidikan dan pelatihan personal dapat memoderasi pengaruh Kecanggian Teknologi Personal terhadap kinerja sistem informasi akuntansi.

$\mathrm{H}_{6}$ : Pendidikan dan pelatihan memoderasi pengaruh kecanggian teknologi personal terhadap kinerja sistim informasi akuntansi.

\section{Metode Penelitian}

Jenis penelitian ini adalah penelitian kuantitatif yg menekankan pada pengujian teori-teori dengan melakukan pengukuran variabel-variabel penelitian dengan angka atau bilangan lalu melakukan analisis data dengan prosedur statistik melalui uji hipotesis. Penelitian ini menggunakan desain penelitian kasual yang oleh Sugiyono (2016) adalah 
hubungan yang bersifat sebab akibat. Pengumpulan data penelitian ini menggunakan metode kuesioner yang merupakan teknik pengumpulan data yang dilakukan dengan cara memberikan seperangkat pertanyaan tertulis kepada responden untuk menjawabnya (Sugiyono 2016).

Populasi dalam penelitian ini adalah seluruh karyawan/pegawai PT. PLN (persero) Kabupaten Jayapura. Teknik sampel yang digunakan adalah Purposive sampling dengan menggunakan beberapa kriteria yakni; supervisor dan pegawai unit akuntansi, anggaran, niaga dan pegawai yang terlibat dalam penyusunan laporan keuangan dengan status aktif sebanyak 82 Responden.

Jenis data yang digunakan dalam penelitian ini adalah data primer yang diperoleh dari jawaban responden terhadap item-item pertanyaan yang terdapat dalam kuesioner. Skala pengukuran jawaban responden menggunakan skala likert, yaitu; skala antara 1 sampai dengan 5. Skor 1 untuk "Sangat Tidak Setuju (STS)", skor 2 untuk "Tidak Setuju (TS)", skor 3 untuk "Netral (N)", skor 4 untuk "Setuju (S)" dan skor 5 untuk "Sangat Setuju (SS)" yang diadopsi dari Ningrum, (2019).s

Variabel yang diteliti dalam kajian ini antara lain; variabel sistem informasi akuntansi adalah penyedia informasi keuangan yang dibutuhkan oleh pihak-pihak yang berkepentingan dengan perusahaan. Pihak-pihak yang berkepentingan dalam penggunaan informasi keuangan yakni pihak eksternal dan internal. Indikator pengukuran untuk sistem informasi akuntansi adalah akurat dan teruji kebenarannya, kesempurnaan informasi, tepat waktu, relevansi, mudah dan murah. Item pertanyaan untuk variabel sistem informasi akuntansi mengadopsi pada penelitian Astuti, (2008).

Variabel berikutnya adalah kemampuan teknik personal. Kemampuan teknik sistem informasi sangat bermanfaat dan berperan penting dalam pengembangan sistem informasi untuk dapat menghasilkan informasi guna menciptakan laporan perencanaan yang akurat. Selain itu suatu sistem informasi akan lebih bermanfaat dalam membantu aktivitas apabila personel yang menggunakan sistem informasi tersebut, memiliki kemampuan untuk mengoperasikan sistem informasi tersebut. Indikator terkait kemampuan teknik personal dalam penelitian ini adalah Knowledge (pengetahuan), Abilities dan Skill. Variabel selanjutnya adalah pemakai sistem informasi. Menurut Susanto (2008) para pemakai sistem informasi sebagian besar merupakan orang-orang yang hanya akan mengunakan sistem informasi yang telah dikembangkan seperti 
operator dan manajer (end user). Indikator untuk mengukur keterlibatan pemakai adalah partisipasi, pendapat, pengaruh, dan keterlibatan (Jen, 2002).

Varibel berikutnya Menurut pelatihan dan pendidikan. Mathis (2012) mengatakan bahwa pelatihan adalah suatu proses dimana orang-orang mencapai kemampuan tertentu untuk membantu mancapai tujuan organisasi. Menurut UU No. 20 Tahun 2003 tentang SISDIKNAS, yakni menjelaskan pendidikan adalah usaha sadar dan terencana untuk mewujudkan suasana belajar dan proses pembelajaran agar peserta didik secara aktif mengembangkan potensi dirinya untuk memiliki kekuatan spiritual keagamaan,pengendalian diri kepribadian, kecerdasan, akhlak mulia, serta keterampilan yang diperlukan dirinya, masyarakat, bangsa dan negara.

Selanjutnya yang terakhir adalah variabel kecanggihan teknologi informasi merupakan suatu kebutuhan bagi organisasi yang dapat membantu kinerja organisasi dan individu. Menurut Haag dan Keen (1996) teknologi informasi adalah seperangkat alat yang membantu seseorang bekerja dengan informasi dan melakukan tugas-tugas yang berhubungan dengan pemrosesan informasi. Indikator kecanggihan teknologi mengenai terkomputerisasi dan terintegrasi memperoleh skor yang paling tinggi.

Pengujian kualitas data dilakukan untuk memenuhi kualitas berupa konsistensi dan akurasi data yang dikumpulkan melalui instrument penelitian. Uji ini perlu dilakukan karena jenis data penilaian adalah data primer, jenis peguji berupa uji validitas dan reliabilitas, yaitu: Uji validitas menggunakan pengujian construct validity yang dilakukan dengan teknik korelasi antar skor butir pertanyaan dalam suatu variabel yang diamati dengan skor totalnya, dengan menggunakan rumus korelasi product moment dengan level signifikansi $5 \%$ dari nilai kritisnya. Rumus korelasi product moment menurut (Singarimbun, 2006). Sebuah instrumen dikatakan reliabel, jika selalu mendapatkan hasil yang sama dari gejala pengukuran yang tidak berubah yang dilakukan pada waktu yang berbeda-beda (Ghozali, 2013). Menurut (Malhotra, 2005), Reliability adalah indeks yang menunjukan sejauh mana suatu alat ukur dapat dipercaya atau dapat diandalkan. Peneliti melakukan uji reliabilitas dengan menghitung Cronbach's alpha dari masingmasing instrumen dalam suatu variabel.

Uji asumsi klasik merupakan salah satu syarat pengujian hipotesis yang bertujuan untuk menguji persamaan regresi linear agar dapat dikatakan sebagai model yang baik. Uji asumsi klasik ini meliputi uji normalitas, uji multikolonieritas, dan uji heteroskedastisitas: Uji Normalitas Pengujian normalitas data bertujuan untuk 
mengetahui distribusi data dalam variabel yang akan digunakan dalam penelitian. Pengujian normalitas data dalam penelitian ini menggunakan grafik histogram dan probability plot. Menurut Priyatno, (2012) menyatakan bahwa model regresi yang baik seharusnya tidak terjadi heteroskedastisitas. Pengujian heteroskedastisitas dalam kajian ini adalah dengan melihat penyebaran titik-titik pada grafik scatterplot. Uji multikolonieritas bertujuan untuk menguji korelasi antar variabel independen. Model regresi yang baik seharusnya tidak terjadi kolerasi antara variabel independen (Ghozali, 2013). Pengujian multikolonieritas dilakukan dengan menggunakan Variance Inflation Factor(VIF) dan tolerance. Nilai yang umum dipakai untuk menunjukkan tidak terjadinya multikolonieritas adalah nilai tolerance harus $\geq 0,10$ atau sama dengan nilai Variance Inflation Factor (VIF) dari masing-masing variabel $\leq 10$. Untuk menjawab permasalahanpermasalahan penelitian disesuaikan dengan model hipotesis yang menggunakan analisis regresi moderasi (Moderated Regression Analysis).

\section{Pembahasan Hasil Penelitian}

\section{Uji Instrumen Penelitian}

\section{Uji Validitas}

Uji validitas dalam penelitian ini menggunakan perbandingan antara indeks korelasi Product Moment Person dengan signifikan 5\%. Bila probabilitas hasil korelasi lebih kecil dari 0.05 maka instrumen dinyatakan valid. Sebaliknya, jika hasil korelasi lebih besar dari 0,05 maka instrumen dinyatakan tidak valid. Hasil uji ini terangkum pada Tabel berikut;

Tabel Hasil Uji Validitas

\begin{tabular}{|c|c|c|c|c|}
\hline \multirow{2}{*}{ Variabel } & Item & $\begin{array}{c}\text { Koefisien } \\
\text { Korelasi }\end{array}$ & Sig & Ket. \\
\hline \multirow{3}{*}{$\begin{array}{c}\text { Kemampuan Teknik } \\
\text { Personal }\end{array}$} & $\mathrm{X}_{1.1}$ & 0,944 & 0,000 & Valid \\
\cline { 2 - 5 } & $\mathrm{X}_{1.2}$ & 0,903 & 0,000 & Valid \\
\cline { 2 - 5 } & $\mathrm{X}_{1.3}$ & 0,878 & 0,000 & Valid \\
\cline { 2 - 5 } & $\mathrm{X}_{1.4}$ & 0,888 & 0,000 & Valid \\
\hline \multirow{4}{*}{ Keterlibatan Pemakai } & $\mathrm{X}_{2.1}$ & 0,824 & 0,000 & Valid \\
\cline { 2 - 5 } & $\mathrm{X}_{2.2}$ & 0,731 & 0,000 & Valid \\
\cline { 2 - 5 } & $\mathrm{X}_{2.3}$ & 0,715 & 0,000 & Valid \\
\cline { 2 - 5 } & $\mathrm{X}_{2.4}$ & 0,774 & 0,000 & Valid \\
\cline { 2 - 5 } & $\mathrm{X}_{2.5}$ & 0,781 & 0,000 & Valid \\
\hline \multirow{3}{*}{ Kecanggian Teknologi } & $\mathrm{X}_{3.1}$ & 0,854 & 0,000 & Valid \\
\cline { 2 - 5 } Informasi & $\mathrm{X}_{3.2}$ & 0,773 & 0,000 & Valid \\
\cline { 2 - 5 } & $\mathrm{X}_{3.3}$ & 0,773 & 0,000 & Valid \\
\cline { 2 - 5 } & $\mathrm{X}_{3.4}$ & 0,838 & 0,000 & Valid \\
\hline \multirow{2}{*}{\begin{tabular}{c} 
Pendidikan dan Pelatihan \\
\cline { 2 - 5 }
\end{tabular}} & $\mathrm{Z}_{1.1}$ & 0,698 & 0,000 & Valid \\
\cline { 2 - 5 } & $\mathrm{Z}_{1.2}$ & 0,700 & 0,000 & Valid \\
\hline
\end{tabular}




\begin{tabular}{|c|c|c|c|c|}
\hline Variabel & Item & $\begin{array}{c}\text { Koefisien } \\
\text { Korelasi }\end{array}$ & Sig & Ket. \\
\hline \multirow{4}{*}{$\begin{array}{c}\text { Kinerja Sistem Informasi } \\
\text { Akuntansi }\end{array}$} & $\mathrm{Z}_{1.3}$ & 0,743 & 0,000 & Valid \\
\cline { 2 - 5 } & $\mathrm{Z}_{1.4}$ & 0,740 & 0,000 & Valid \\
\cline { 2 - 5 } & $\mathrm{Z}_{1.5}$ & 0,665 & 0,000 & Valid \\
\cline { 2 - 5 } & $\mathrm{Y}_{1.1}$ & 0,744 & 0,000 & Valid \\
\cline { 2 - 5 } & $\mathrm{Y}_{1.2}$ & 0,632 & 0,000 & Valid \\
\cline { 2 - 5 } & $\mathrm{Y}_{1.3}$ & 0,764 & 0,000 & Valid \\
\cline { 2 - 5 } & $\mathrm{Y}_{1.4}$ & 0,902 & 0,000 & Valid \\
\cline { 2 - 5 } & $\mathrm{Y}_{1.5}$ & 0,902 & 0,000 & Valid \\
\hline
\end{tabular}

Hasil pengujian validitas diatas dapat disimpulkan valid, karena tingkat probabilitasnya (sig) atau tingkat signifikannya < dari 0,05.

\section{Uji Reliabilitas}

Uji reliabitas dilakukan untuk menghasilkan ukuran pernyataan yang konsisten. Menurut (Sugiono, 2017), reliabilitas adalah derajat konsistensi atau keajegan data dalam interval waktu tertentu. Pengukuran reliabilitas dilakukan dengan cara pengukuran sekali saja dengan alat bantu SPSS 23.00 uji statistik Cronbach Alpha based on standardized items. Suatu konstruk atau variabel dikatakan reliabel jika memberikan nilai output SPSS bahwa konstruk variabel memberikan nilai Cronbach Alpha based on standardized items $>0.70$ yang menurut (Ghozali, 2013) bisa dikatakan reliabel seperti disajikan dalam Tabel berikut.

Tabel Hasil Uji Realibilitas

\begin{tabular}{|l|c|c|}
\hline \multicolumn{1}{|c|}{ Variabel } & Cronbach A/pha & Keterangan \\
\hline Kemampuan Teknik Personal & 0,925 & Reliabel \\
\hline Keterlibatan Pemakai & 0,823 & Reliabel \\
\hline Kecanggian Teknologi Informasi & 0,825 & Reliabel \\
\hline Pendidikan dan Pelatihan & 0,753 & Reliabel \\
\hline Kinerja Sistem Informasi Akuntansi & 0,849 & Reliabel \\
\hline
\end{tabular}

Paparan hasil uji reliabilitas dalam penelitian ini di sajikan dalam tabel. Hasil uji di atas menunjukkan bahwa keofisien Cronbach Alpha based on standardized items $>0.60$ sehingga dapat disimpulkan bahwa data kelima variabel terteliti adalah reliabel.

\section{Uji Asumsi Klasik}

\section{Normalitas}

Pengujian normal tidaknya dostribusi data penelitian ini dilakukan dengan melihat peneyebaran data pada normal probabilityplot. Tampilan hasil pengujian normal probabilityplot data penelitian ini terlihat dibawah ini. 


\section{Gambar Hasil Pengujian Normalitas}

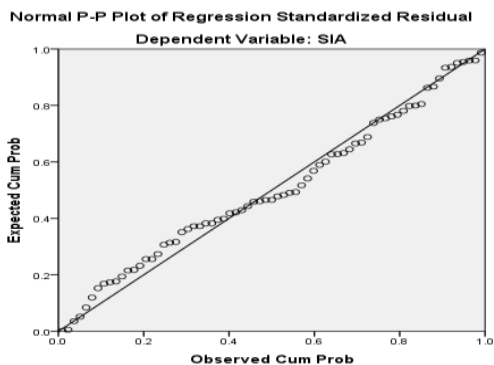

Grafik normal probability plot dalam Gambar diatas menunjukkan bahwa titik-titik data menyebar di sekitar garis diagonal serta penyebarannya mengikuti arah garis diagonal, dengan demikian sebaran data dapat dikatakan berdistribusi normal, sehingga bisa dilakukan regresi dengan model linear berganda. Uji normalitas menggunakan Kolmogrov-smirnov dengan nilai p-Kolmogrov-smirnov test >0,05 (Ghozali, 2013).

\section{Heterokedastisitas}

Pengujian heteroskedastisitas dalam penelitian ini dilakukan dengan melihat gambar charts scatterplot. Berikut ini adalah hasil pengujian heteroskedastisitas yang terlihat pada gambar charts scatterplot dibawah ini.

\section{Gambar Hasil Pengujian Heterokedastisitas}

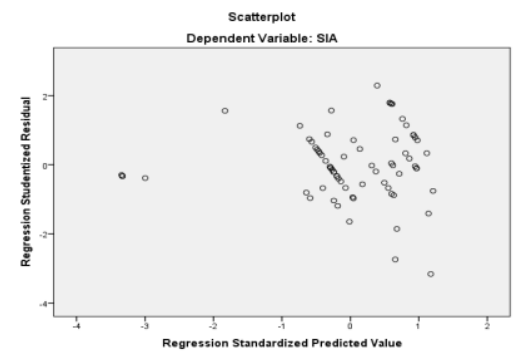

Gambar diatas menunjukkan bahwa data penelitian bebas heterokedastisitas karena titik-titik data menyebar diatas dan dibawah angka 0 pada sumbu $Y$

\section{Multikoliniearitas}

Pengujian multikolinearitas kajian ini menggunakan melihat nilai Variance Inflation Faktor (VIF) atau faktor pertambahan ragam. Apabila nilai VIF > 10 maka terjadi multikolinieritas, sebaliknya apabila VIF < 10 maka tidak terjadi multikolinieritas . Hasil analisis menunjukan bahwa tidak terjadi gejala multikoliniearitas seperti yang terlihat dibawah ini. 
Tabel Pengujian Multikolinieritas

\begin{tabular}{|l|c|c|}
\hline \multirow{2}{*}{ Model } & \multicolumn{2}{c|}{ Collinearity } \\
\cline { 2 - 3 } & Tolerance & VIF \\
\hline Kemampuan Teknik Personal & 0,152 & 6,597 \\
\hline Keterlibatan Pemakai & 0,163 & 6,121 \\
\hline Kecanggian Teknologi Informasi & 0,204 & 2,869 \\
\hline
\end{tabular}

\section{Pembahasan Hasil Penelitian}

\section{Kemampuan Teknik Personal Berpengaruh Terhadap Kinerja Sistem Informasi Akuntansi}

Berdasarkan hasil uji parsial variabel kemapuan teknik personal menunjukkan $t_{\text {hitung }}$ sebesar 0,693 . Sementara nilai $t_{\text {tabel }}$ sebesar 1,675 sehingga $t_{\text {hitung }}<t_{\text {tabel }}(0,693<1,675)$ dengan probabilitas signifikansi sebesar 0,491 > 0,05. Hasil tersebut membuktikan bahwa kemampuan teknik personal tidak berpengaruh terhadap kinerja sistem informasi akuntansi.

Teori yang mendukung hubungan kemampuan teknik personal sistem informasi adalah teori pencapaian prestasi. Teori ini menyatakan bahwa perubahan perilaku muncul karena individu ingin berhasil. Individu yang memiliki predisposisi yang kuat untuk mengerjakan sesuatu dengan lebih baik, memiliki kemungkinan yang tinggi untuk membuat perubahan memperoleh sesuatu asumsi lain yang lebih penting adalah jika seseorang menghabiskan waktu berpikirnya untuk melakukan sesuatu yang baik, maka orang tersebut akan menampakkan dorongan energi dan hasrat ingin sukses serta akan meraih tujuan yang lebih besar. Keberhasilan suatu pengembangan sistem informasi tidak hanya ditentukan oleh kecanggihan sistem tersebut tetapi ditentukan oleh kesesuaiannya dengan para pemaki sistem tersebut. Semakin rendah tingkat kemampuan teknik personal maka tingkat kinerja sistem informasi akuntansi yang dihasilkan akan semakin rendah, begitu pula sebaliknya. Hasil penelitian ini didukung oleh penelitian sebelumnya yang dilakukan oleh (Gultom, 2020) yang menyatakan bahwa kemampuan teknik personal berpengaruh pada kinerja sistem informasi akuntansi.

\section{Keterlibatan Pemakai Berpengaruh Terhadap Kinerja Sistem Informasi Akuntansi}

Berdasarkan hasil uji parsial variabel keterlibatan pemakai menunjukkan $t_{\text {hitung }}$ sebesar 2,466 . Sementara nilai $t_{\text {tabel }}$ sebesar 1,675 sehingga $t_{\text {hitung }}>t_{\text {tabel }}(2,466>1,675)$ dengan probabilitas signifikansi sebesar 0,016 $<0,05$. Hasil tersebut membuktikan 
bahwa keterlibatan pemakai berpengaruh positif dan signifikan terhadap kinerja sistem informasi akuntansi.

Teori yang mendukung hasil penelitian ini adalah teori Y dari (Mc Gregor, 1960). Teori ini menyatakan bahwa orang-orang akan mengarahkan dan mengendalikan diri sendiri untuk mencapai tujuan apabila mereka merasa terikat dengan tujuan itu. Dalam kondisi yang sesuai, mereka belajar menerima dan mencari tanggung jawab. Namun jika kondisi lingkungan tidak mendukung maka keterlibatan pemsakai tidak akan meemiliki dampak yang besar. Hal tersebut terjadi karena pemakai sistem informasi kurang dilibatkan dalam pemakaian sistem itu sendiri, sehingga pemakai tidak merasa puas.

Hasil penelitian ini berhasil membuktikan hubungan pengaruh yang signifikan antara keterlibatan pemakai sistem informasi terhadap kepuasan pemakai maupun pemakaian sistem tersebut. Hasil ini cenderung disebabkan karena responden merasa tertarik dalam pengembangan maupun pemakain sistem padahal keterlibatan yang semakin sering akan meningkatkan kinerja sistem informasi akuntansi dikarenakan adanya hubungan yang positif antara keterlibatan atau partisipasi pemakai dalam proses pengembangan sistem informasi dalam kinerja sistem informasi akuntansi, selain itu tingkat partisipasi responden yang rendah dalam pemakaian sistem informasi. Hal ini dapat dipahami karena hanya sebagian besar karyawan yang memahami karakteristik sistem informasi dan ahli dalam bidang sistem informasi. Sebaiknya pihak PT. PLN Persero unit layanan pelanggan Kabupaten Jayapura memperhatikan kemampuan yang dimiliki oleh pengguna sistem informasi akuntansi masing-masing baik dari segi kemampuan dasar mereka mengenai pengoperasian komputer maupun kemampuan mereka mengenai sistem yang djalankan tersebut sehingga, pihak PT. PLN Persero unit layanan pelanggan Kabupaten Jayapura dapat mengoptimalkan kemampuan para pengguna sistem informasi akuntansi agar menghasilkan kinerja yang lebih baik.

Hasil penelitian ini didukung oleh penelitian sebelumnya yang dilakukan oleh Ardiwinata dan Sujana (2019) yang menunjukkan bahwa keterlibatan pemakai berpengaruh positif dan signifikan terhadap kinerja sistim informasi akuntansi pada LPD di Kota Denpasar namun hasil penelitiannya tidak sejalan dengan penelitian Alchan, dkk (2016) yang menyimpulkan hasil yang berbeda yakni, keterlibatan pemakai tidak berpengaruh terhadap kinerja sistem informasi akuntansi pada PT. PLN (Persero) Distribusi Jawa Barat. 


\section{Kecanggihan Teknlogi Informasi Berpengaruh Terhadap Kinerja Sistem Informasi Akuntansi}

Berdasarkan hasil uji parsial variabel kecanggihan teknlogi informasi menunjukkan $t_{\text {hitung }}$ sebesar 6,606. Sementara nilai $t_{\text {tabel }}$ sebesar 1,675 sehingga $t_{\text {hitung }}>t_{\text {tabel }}(6,606>$ $1,675)$ dengan probabilitas signifikansi sebesar 0,000 $<0,05$. Hasil tersebut membuktikan bahwa kecanggihan teknlogi informasi berpengaruh terhadap sistim informasi akuntansi.

Kaitan Teori TAM dengan variabel kualitas SIA dan Kecanggihan Teknologi yang digunakan, yaitu menurut (Saputri, 2016) ketika suatu sistem dikatakan berkualitas maka sistem tersebut akan bermanfaat. Begitu juga jika suatu sistem menggunakan teknologi yang canggih maka manfaat dari sistem tersebut juga akan meningkat. Karena kecanggihan teknologi tersebut menghasilkan beraneka ragam teknologi sistem yang dirancang untuk membantu pekerjaan manusia dalam menghasilkan informasi yang terbaik. Namun jika kecanggihan tersebut tidak didukung oleh pengguna (operator) yang handal dan juga lingkungan dimana teknologi tersebut digunakan tidak mendukung maka teknologi sebaik apapun akan menjadi percuma.

Kehadiran teknologi merupakan sumber kekuatan yang menjadikan sebuah perusahaan memiliki keunggulan kompetitif, serta diidentifikasikan sebagai faktor yang memberikan retribusi terhadap keberhasilan perusahaan. Oleh karena itu teknologi informasi memiliki pengaruh yang tinggi terhadap keberhasilan perusahaan dalam mengelola perusahaannya. Sehingga semakin canggih teknologi informasi yang diterapkan maka efektivitas sistem informasi yang dihasilkan akan semakin tinggi pula selain pengaruh dari user pengguna informasi. Namun daerah papua seringkali mengalami gangguan internet ataupun pemutusan jaringan. Hal tersebut pastinya berdampak pada penggunaan sistem. Selain itu masih banyak daerah-daerah yang mengalami ketertingalan dalam akses internet.

Hal ini yang menjadi alasan mengapa kecanggihan teknologi informasi memiliki pengaruh terhadap sistem informasi akuntansi. Seberapa canggihnya teknologi informasi yang dimiliki dan akses yang mendukung maka akan baik dalam pelayanan. Hasil penelitian ini didukung oleh penelitian sebelumnya yang dilakukan oleh Penelitian Ratnasih, dkk (2017) yang menunjukkan bahwa kecanggihan teknologi informasi berpengaruh positif dan signifikan terhadap kinerja sistem informasi akuntansi. namun hasil penelitiannya tidak sejalan dengan penelitian Nanda (2016) yang menyatakan 
bahwa kecanggihan teknlogi informasi tidak berpengaruh terhadap Sistem informasi akuntansi.

\section{Pelatihan dan Pendidikan Moderasi Pengaruh Kemampuan Teknik Personal Terhadap Kinerja Sistem Informasi Akuntansi}

Berdasarkan hasil yang diajukan dalam penelitian ini adalah terdapat pengaruh kemampuan teknik personal terhadap kinerja sistem informasi akuntansi. Berdasarkan data yang diolah diketahui bahwa nilai thitung sebesar 12,646 dengan signifikansi 0,000 lebih besar dari nilai $p$ value 0,05. Dengan demikian, dapat disimpulkan bahwa pelatihan dan pendidikan memoderasi hubungan kemampuan teknik personal terhadap kinerja sistim informasi akuntansi.

Kemampuan teknik personal tidak lepas dari penerapan teknologi, kemampuan pemakai dapat dilihat dari bagaimana pemakai sistem dapat menggunakan Kinerja sistim informasi akuntansi hal ini penting dalam mengoperasikan agar system dapat beroperasi secara maksimal. Untuk itu pelatihan dan pendidikan seorang karyawan perlu di tingkatkan lagi agar dapat memberikan perubahan terhadap kinerja PT. PLN kedepannya. Hasil penelitian diatas tidak sejalan dengan penelitian (Gusi Putu Lestara Permana, 2020) menyatakan bahwa Pelatihan dan Pendidikan tidak mampu memperkuat kemampuan teknik personal pada kinerja sistem informasi akuntansi.

\section{Pelatihan dan Pendidikan Memoderasi Pengaruh Keterlibatan Pemakai Terhadap Kinerja Sistem Informasi Akuntansi}

Berdasarkan hasil yang diajukan dalam penelitian ini adalah terdapat pengaruh keterlibatan pemakai terhadap kinerja sistem informasi akuntansi. Berdasarkan data yang diolah diketahui bahwa nilai thitung sebesar 12,781 dengan signifikansi 0,000 lebih besar dari nilai $p$ value 0,05 . Dengan demikian, dapat disimpulkan bahwa pelatihan dan pendidikan memoderasi hubungan keterlibatan pemakai terhadap kinerja sistim informasi akuntansi.

Keterlibatan pemakai yang semakin sering akan meningkatkan kinerja sistem informasi akuntansi dikarenakan adanya hubungan positif antara keterlibatan pemakai terhadap kinerja sistem informasi akuntansi. Adanya keterlibatan pemakai dapat meningkatkan penerimaan sistem oleh pemakai. Dengan adanya Pelatihan dan Pendidikan dapat meningkatkan pemahaman pemakai tentang sistem informasi yang digunakan, selain itu dapat meningkatkan komitmen dan ketelibatan pemakai dalam pengembangan sistem, sehingga pemakai dapat menggunakan sistem informasi dan 
dapat meningkatkan kualitas kinerja sistem informasi akuntansi dalam pengembangan sistemnya. Hasil konsisten dengan penelitian. (Gusi Putu Lestara Permana, 2020), menunjukan pelatihan dan pendidikan mampu memperkuat keterlibatan pemakai pada kinerja sistem infomasi akuntansi.

\section{Pelatihan dan Pendidikan Memoderasi Pengaruh Kecanggian Teknologi Personal Terhadap Kinerja Sistem Informasi Akuntansi}

Berdasarkan hasil yang diajukan dalam penelitian ini adalah terdapat pengaruh kecanggian teknologi personal terhadap kinerja sistem informasi akuntansi. Hasil data yang diolah diketahui bahwa nilai thitung sebesar 15,855 dengan signifikansi 0,000 lebih besar dari nilai $p$ value 0,05 . Dengan demikian, dapat disimpulkan bahwa pelatihan dan pendidikan memoderasi hubungan kecanggian teknologi personal terhadap kinerja sistim informasi akuntansi.

Menurut (Keen., 1996), teknologi informasi adalah seperangkat alat yang memebantu anda bekerja dengan informasi dan melakukan tugas-tugas yang berhubungan dengan pemrosesan informasi. Untuk itu Dalam pelaksanaan System Application and Product (SAP) dapat mempermuda karyawan dalam melaksanakan sebuah pekerjaan dengan efektif dan efisien pada PT. PLN Persero Unit Layanan Pelanggan Kabupaten Jayapura. Menurut penelitian yang dilakukan oleh (Alannita, 2014) dan (Fani, Luh Nanda Yogita \& Ayu, 2015) menunjukan bahwa kecanggihan teknologi informasi terdapat pengaruh yang signifikan terhadap kinerja individu.

\section{Penutup}

\section{Kesimpulan}

Berdasarkan pembahasan hasil penelitian maka kesimpulan yang dapat disampaikan melalui penelitian ini adalah sebagai berikut: 1). Kemampuan teknik personil tidak berpengaruh terhadap Kinerja sistim informasi akuntansi pada PT. PLN Persero Unit Layanan Pelanggan Kabupaten Jayapura, 2). Keterlibatan pemakai berpengaruh terhadap Kinerja sistim informasi akuntansi pada PT. PLN Persero Unit Layanan Pelanggan Kabupaten Jayapura, 3). Kecanggihan teknologi personil berpengaruh terhadap Kinerja sistim informasi akuntansi pada PT. PLN Persero Unit Layanan Pelanggan Kabupaten Jayapura, 4). Pelatihan dan pendidikan memoderasi kemampuat teknik personil terhadap Kinerja sistim informasi akuntansi pada PT. PLN Persero Unit Layanan Pelanggan Kabupaten Jayapura, 5). Pelatihan dan pendidikan 
memoderasi keterlibatan pemakai terhadap Kinerja sistim informasi akuntansi pada PT. PLN Persero Unit Layanan Pelanggan Kabupaten Jayapura dan yang terakhir 6). Pelatihan dan pendidikan memoderasi kecanggihan teknologi personil terhadap Kinerja sistim informasi akuntansi pada PT. PLN Persero Unit Layanan Pelanggan Kabupaten Jayapura.

\section{Saran}

Adapun saran dalam penelitian ini baik bagi PT. PLN, masyarakat maupun akademisi untuk penelitian selanjutnya adalah sebagai berikut: 1). Dalam penelitian ini penulis menggunakan sampel sebanyak 71 responden. Maka diharapkan penelitian selanjutnya dapat menambahkan jumlah responden. 2). Bagi penelitian selanjutnya diharapkan dapat menambahkan variabel lain seperti dukungan manajemen puncak sebagai variabel independen ataupun menjadikannya sebagai variabel moderasi. 3). Bagi pihak PT. PLN diharapkan dapat menggunakan hasil penelitian ini sebagai bahan evaluasi kinerja dalam pemanfaatan sistem informasi akuntansi yang lebih baik lagi

\section{Daftar Pustaka}

Adiwinata, I. G., \& Sujana, I. K. (2019). Pengaruh Kemampuan Teknik Personal, Keterlibatan Pemakai, Pelatihan Dan Pendidikan Pada Kinerja Sistem Informasi $\begin{array}{llll}\text { Akuntansi. E-Jurnal } & \text { Akuntansi, 27, }\end{array}$ https://doi.org/10.24843/eja.2019.v27.i03.p09

Alannita, N. P. dan I. G. N. A. S. (2014). Pengaruh Kecanggihan Teknologi Informasi, Partisipasi Manajemen, dan Kemampuan Teknik Pemakai Sistem Informasi Akuntansi pada Kinerja Individu. Jurnal Akuntansi, 33-45.

Alchan, I. H., Rahayu, S., \& Muslih, M. (2016). Pengaruh Kemampuan Pengguna Sistem Informasi, Pimpinan Bagian, Dan Program Pendidikan Dan Pelatihan (Studi Pada PT PLN (Persero) Distribusi Jawa Barat). E-Proceeding of Management, 3(3), 32923297.

Ardiwinata, \& Sujana. (2019). Pengaruh Kemampuan Teknik Personal, Keterlibatan Pemakai, Pelatihan Dan Pendidikan Pada Kinerja Sistem Informasi Akuntansi. EJurnal Akuntansi Universitas Udayana, 272302-8556), 1867-1896. https://doi.org/https://doi.org/10.24843/EJA.2019.v27.i03.p09

Astuti, T. (2008). Pengaruh Penerapan Sistem Informasi Akuntansi Terhadap Kinerja Individu. Universitas Brawjaya Malang.

Fani, Luh Nanda Yogita, D. N. A. S. dan P. I. G., \& Ayu. (2015). Pengaruh Kecanggihan Teknologi Informasi, Kemampuan Teknik Pemakai, Dan Dukungan Manajemen Puncak Terhadap Kinerja Sistem Informasi Akuntansi Studi Empiris pada PT PLN (Persero) Area Bali Utara (Kantor Pusat). Jurnal Akuntansi.

Fani, Luh Nanda; Darmawan,Nyoman; Purnamawati, I. G. (2015). Pengaruh Kecanggihan Teknologi Informasi, Kemampuan Teknik Pemakai, dan Dukungan Manajemen 
Puncak Terhadap Kinerja Sistem Informasi Akuntansi Studi Empiris pada PT PLN (Persero) Area Bali Utara (Kantor Pusat). E-Journal S1 Ak Universitas Pendidikan Ganesha, 3(1), 1-12.

Faradiza, S. A. (2018). Persepsi Keadilan, Sistem Perpajakan dan Diskriminasi Terha dap Etika Penggelapan Pajak. Jurnal Akuntansi, 11(1), 53-74. https://doi.org/10.15408/akt.v11i1.8820

Ghozali, I. (2013). Analisa Multivariate dengan Program SPSS. Universitas Diponegoro.

GULTOM, A. (2020). Analisis Faktor - Faktor Yang Mempengaruhi Kinerja Sistem Informasi Akuntansi Pada PT. Cahaya Globalindo Prima. Jurnal Akuntansi.

Gusi Putu Lestara Permana, I. W. A. S. (2020). Pengaruh Keterlibatan Pemakai Dan Kemampuan Teknik Personal Pada Kinerja Sistem Informasi Akuntansi Dengan Pendidikan Dan Pelatihan Sebagai Variabel Pemoderasi (Studi Empiris Pada Lembaga Perkreditan Desa di Kecamatan Denpasar Selatan) (Studi Empiris Pada. Jurnal Ilmiah Akuntansi Dan Bisnis, Vol 5, No, 49-66.

Haag dan Keen. (1996). Information Technology: Tomorrow's Advantage Today. Hammond: Mcgraw-Hill College.

Jen, T. F. (2002). Faktor-faktor yang mempengaruhi Kinerja Sistem Informasi Akuntansi. Jurnal Bisnis Dan Akuntansi, 4 No 2, 135-154.

Keen., H. dan. (1996). Information Technology: Tomorrow's Advantage Today. Hammond: Mcgraw-Hill College.

Malhotra, N. K. (2005). Riset Pemasaran: Pendekatan Terapan, Terjemahan oleh: Ir. Soleh Rusyadi Maryam,MM (Edisi Keem). PT. INDEKS, .

Mathis, R. L. dan J. H. J. (2012). Manajemen Sumber Daya Manusia. Buku 1, Alih Bahasa: Jimmy Sadeli dan Bayu. Prawira Hie. Salemba Empat.

Mc GREGOR. (1960). The Human Side of Enterprise New York McGraw-Hill.

Ningrum, H. (2019). ( Studi Kasus Pada PT . PLN PERSERO UP3 Klaten ) Disusun Oleh: Universitas Muhammadiyah Surakarta.

Priyatno. (2012). Cara Kilat belajar Analisa Data Dengan SPSS 20 (1st ed.). Andi Ofset.

Purwa Abhimantra, W., \& Suryanawa, I. (2016). Analisis Faktor-Faktor Yang Memengaruhi Kinerja Sistem Informasi Akuntansi. E-Jurnal Akuntansi, 14(3), 17821809.

Putri, N. W., \& Dharmadiaksa, I. (2015). Pengaruh Kemampuan Teknik Personal, Program Pelatihan dan Pendidikan, Insentif, dan Partisipasi Manajemen Pada Kinerja Penerapan SIA. E-Jurnal Akuntansi, 12(3), 582-592.

Putu Ardiwinata, I. G. N., \& Sujana, I. K. (2019). Pengaruh Kemampuan Teknik Personal, Keterlibatan Pemakai, Pelatihan Dan Pendidikan Pada Kinerja Sistem Informasi $\begin{array}{llllll}\text { Akuntansi. E-Jurnal } & \text { Akuntansi, } 29 & \text { No } & 3, & \end{array}$ https://doi.org/10.24843/EJA.2019.v27.i03.p09

Ratnasih, K. S., \& Sujana, E. ;Ni K. (2017). Pengaruh Kecanggihan Teknologi Informasi, Pertisipasi Pengguna, dan Kemampuan Pengguna Terhdap KInerja Sistem Informasi Akuntansi Pada PT PLN (PERSERO) Area Bali Utara (Kantor Pusat). EJournal S1 Ak Universitas Pendidikan Ganesha, ス1). 
Saputri, I. N. (2016). Pengaruh Kualitas Sistem Informasi Akuntansi Terhadap Kepuasan Pengguna Paket Program Aplikasi Sistem Infomasi Akuntansi (Studi Empiris Pada Bank Perkreditan Rakyat Boyolali).Surakarta: Universitas Muhammadiyah Surakarta. Jurnal Akuntansi.

Satria, I. G. N., \& Wahyu dan Putra, I. N. A. (2019). E-Jurnal Akuntansi Universitas Udayana Pengaruh Kemampuan Teknik Personal , Keterlibatan Pemakai , Pendidikan dan Pelatihan pada Efektivitas Penggunaan Sistem Informasi Akuntansi Fakultas Ekonomi dan Bisnis Universitas Udayana ( Unud ), Bali , Indonesia P. EJurnal Akuntansi Universitas Udayana, 26, 763-790.

Seto, B. D. (2013). Definisi SAP (System Application and Product in data processing), (Online), (http://bagusdwiseto. blogspot.com/2013/04/definisi-sapsystemapplication-and. html, diakses 5 Februari 2015.

Singarimbun, M. dan S. E. (2006). Metode Penelitian Survei (Editor). LP3ES.

Sugiyono. (2016). Metode Penelitian Kuantitatif, Kualitatif, dan Campuran. Refika Aditama.

Susanto, A. (2008). Sistem Informasi Akuntansi. Gramedia.

Undang-Undang Republik Indonesia No 25 Tahun 2009 Tentang Pelayanan Publik. (2009).

UU No. 20 Tahun 2003 tentang SISDIKNAS. (2003). UU No. 20 Tahun 2003 tentang SISDIKNAS. 